\title{
Die oorsprong van die Siriese Christendom
}

Van die oorsprong en vroegste verloop van die Siriese' Christendom is nie veel bekend nie. Ongelukkig ontbreek die skriftelike bronne ons hier omtrent geheel en al. Ons moet ons dus hoofsaaklik laat lei deur indirekte bronne. afleidings en gissings.: Daar bestaan slegs een bron wat voorgee dat dit die oorsprong van die Christendom in Edessa ken en beskrywe. nl. die sg. ..Leer van Addai“. ${ }^{3}$ Enkele geleerdes heg wel enige waarde aan die gegewens van hierdie geskrif. Dic meeste beskou dit egter as in blote legende, vol onjuisthede. waaraan geen waarde geheg kan word nie. Kortliks kom die inhoud van dié deel van die geskrif. wat vir ons hier van belang is, hierop neer: Abgar l lkkama. koning van Edessa. het in afvaardiging na Sabinus te Eleutheropolis gestuur in die jaar 3431 van die Grieke. tyclens die regering van keiser Tiberius. In Palestina verneem Abgar se edelmanne Marihab en Shamshagram. saam met hulle sekretaris Hannan. van Jesus. Hulle besluit om self na Hom te gaan luister. .I. n nadat hulle Jerusalen binnegegaan het. het hulle die Messias gesien en hulle verheug saam met die skare wat by Hon was. Hulle het ook die Iode in groepe sien staan en beraadslaag oor wat hulle met Hom moes doen ondat hulle onthuts was on te sien dat in aantal van hulle mense Hom bely. En hulle was tien dae lank in Jerusalem. en Hannan. die Sekretaris. het alles neergeskrywe wat hy dic Messias sien doen het". Hierna het hulle teruggegaan na Edessa en aan koning Abgar alles meegedeel wat hulle gesien en gehoor het. Abgar wou daarop self na Palestina toe gaan. maar was tog bang om die Romeinse gebied hinne te gaan. Daarom het hy Hannan met in brief na Jesus gestuur waarin hy Hom nooi on na Edessa te kon ondat hy verneem het dat die Jode Jesus om die lewe wil bring en dal daar in Edessa genoeg ruimte vir hulle albei is. Jesus, die ..Goeie (ieneesheer". kan hom dan terselfdertyd ook genees van sy siekte.

Nadat Jesus Abgar se brief in die huis van Gamaliel. die owerste van die Jode(!). ontvang het sou $\mathrm{Hy}$ op sy beurt weer aan Abgar laat weet het: .Gaan, sể aan jou heer wat jou na $M y$ gestuur het: gelukkig is jy ondat. hoewel jy My nie gesien het nie. jy $\log$ in $\mathrm{My}$ geglo het; want dit is aangaande My geskrywe dat hulle wat My sien nie in My sal glo nie. maar hulle wat My nie sien nie. hulle sal in My glo. Nou dan. met betrekking tot dit waaroor jy aan $\mathrm{My}$ geshrywe het. dat tik na jou toe moet kon dit waarvoor Ek hierheen gestuur is. het nou ten einde gekoml" en Ek vaar op na my Vader wat My gestuur hel: maar wanneer Ek na Hom toe gegaan het sal $I k$ aan jou een van my dissipels stuur. sodat. Watter siekte iy ook mag he. hy dit kan genees en gesond maak. En almal wat by jou is. sal hy bekeer tot die ewige liwe en jou stad sal geseend wees en geen vyand sal in ewigheid ooit weer daaroor heerskappy voer nic." 
Ek het hierdie boodskappe breedvoerig weergegee (Jesus s'n aan Abgar volledig gesiteer) vanweë die interessantheid daarvan, maar ook omdat dit gedurende die derde en vierde eeue van ons Christelike jaartelling al wye publisiteit moes geniet het en as die waarheid aanvaar is. Eusebius van Cesaréa (-1 265-339) het die brief van Jesus aan Abgar (met uitsondering van die laaste beloîte daarin - omdat hy geweet het dat dit nie bewaarheid is nie!) reeds in sy Kerkgeskiedenis opgeneem. In die ..Bodleian” Biblioteek te Oxford is daar Griekse papirusfragmente, wat uit die vierde of vyfde eeu dateer, wat 'n Griekse vertaling van hierdie $\mathrm{sg}$. briefwisseling bevat. en gedurende $19(0)$ is ' $n$ latei te Efese gevind waarop hierdie briewe in Griekse letters gegraveer is.'

Ons moet egter terugkeer na Addai toe. Hy verhaal verder hoedat die apostel Judas Thomas" kort na die hemelvaart van Jesus vir Addai. een van die 70 (volgens Addai: 72"). na Edessa toe gestuur het in opvolging van Jesus se belofte. In Edessa gaan Addai tuis by 'n sekere Tobias. die seun van Tobias 'n Palestynse Jood. Abgar word van sy krankheid genees en dadelik tot die Christendom bekeer saam met sy gesin. 'n groot aantal van sy edelliede en van sy onderdane waaronder ook 'n groep Joolse handelaars.

Vir ons doel hier is slegs die slot van hicrdie geskrif weer belangrik. Hierin word verhaal hoedat Adclai 'n natuurlike dool gesterwe het. Hy is opgevolg deur Aggai wat egter, onder Abgar se seun en tweede opvolger. Macnu. 'n marteldood gesterwe het. En nou is die belangrikste dat die verhaal verder meedeel dat Aggai nie, voor sy dool. die geleentheid gehad het om sy opvolger Palut, as biskop te orden nie. Daarvoor moet Palut na Antiochie waar hy deur Serapion tot biskop gewy is. Van Serapion $( \pm 190-211)$ word weer verhaal dat hy deur Zephyrinus $\left( \pm 2(12-218)\right.$, biskop van Rome. ${ }^{1 "}$ tot hiskop gewy is. Tot sover die inhoud van die leer van Addai.

Te midde van al hierdie legendariese en anachronistiese gegewens is daar tog enkele moontlike en, myns insiens, waarskynlike waarheidsmomente of heenwysings in hierdie verhaal (vgl. ook verderaan). Alle ou Kerke het daarna gestrewe om hulle op in ..apostoliese gesag" te kon beroep. d.w.s. hulle het hul oorsprong en stigting probeer toeskrywe aan die optrede van een of ander apostel.

I'it 'n groot deel van die oud-Oosterse (Siriese) Christelike literatuur blyk dit baie duidelik dat Thomas beskou is as die apostel van die Ooste. Sy naam word in verband gebring met die Evangelie. verkondiging tot in Indie." Ander verbind sy naam aan Parthie."

Edessa het hom daarop beroem dat. deur Thomas se toedoen. die Evangelie ook daar verkondig is. Daarom sou Thomas se beendere dan ook gedurende die derde eeu daarheen oorgebring en in Edessa herbegrawe gewees het. ${ }^{13}$ Edessa is die stad van die apostel Thomas. ${ }^{1+}$ Hierdie tradisie word baie duidelik en onomwonde weergegee in die eerste deel van die ..Leer van Addai" soos dit hierbo uitcengesit is: Thonlas het Christus se belofte aan Abgar vervul toe hy vir Addai na Edessa en na Abgar toe gestuur het. Judas Thomas is dus dié 
apostel op wie die Edesseners hulle kan beroep vir hul apostoliese herkoms.

later in die geskrif volg dan in groot anachronisme aangesien Palut. die tweede opvolger van Addai, eers na 190) n.C. tot biskop gewy kon gewees het, indien Serapion van Antiochië dit waargeneen het. soos hier beweer word. Hierby kom ook nog die feit dat Serapion nie deur Zephyrinus as biskop gewy kon gewees het nie omdat hy minstens tien jaar vóór Zephyrinus reeds die biskoplike waardigheid beklee het. Die historiese onjuisthede hierin is duidelik genoeg. van agter gesien. Maar wat is die bedoeling daarvan?

(lit die geskiedenis blyk dit duidelik" dat Sirië se afsondering ongeveer teen die einde van die tweede eeu ten einde begin loop het. Fdessa en omstreke het onder die invloedsfeer van die Romeinse ryk begin $\mathrm{kom}$ en ook die Kerk en Christendom se verwestersing het begin. Daarom moet die Kerk sy gesag nou ook aan 'n westerse setel (apostel) ontleen en - waar kan hiervoor 'n beter persoon gevind word as die biskop van Rome (die opvolger van Petrus!) deur bemiddeling van die biskop van Antiochië"?

Tot sover die ..apostoliese binding" van die Kerk van Edessa. Maar hiernee is die vraag na die corsprong en die tyd van die ontstaan van die Christendom in Edessa (Sirië) nog nie vasgestel nie.

Die enigste ander, nog bestaande skriftelike mededeling in verband met wanneer die Christendom in Edessa sou ontstaan het. vind ons in die apokriewe geskiedenis van Johannes of. soos die volledige opskrif van die Siriese weergawe daarvan lui: ..Die geskiedenis van Johannes. die seun van Sebedéüs, die apostel en evangelis". ${ }^{16}$ Hierin word aan ons meegedeel dat Johannes in Efese gebid het: "Yea, I beseech Thee. l.ord. manifest Thyself here before this assemblage who have believed on Thee with simplicity, and let the nations of the earth hear that the city of Ephesus was the first to receive Thy Gospel before all cities, and become a second sister to Urhai $(=$ Edessa) of the Parthians". 1"

Hierdie .gebedsmededeling" kan alleen dien on aan te dui wat die opvattinge oor die oudheid van die Christendom in Edessa. reeds in Eusebius se tyd of tevore al. in somnige kringe was. ${ }^{14}$

In verband met Adiabene, dit is Arbela en omgewing. weet ons 'n bietjie meer van die verbreiding van die Evangelie aldaar in die vroegste tye. Die Kroniek van Arbela ${ }^{19}$ lig ons hieromtrent in. Peeters ${ }^{20}$ het wel die waarde van hierdie kroniek in twyfel getrek. Ook Burkitt het nie veel notisie daarvan geneem nie. ondat dit nie met sy teorie ooreengestem het nie. Die meeste ander geleerdes is dit egter eens dat ons hier met in baie belangrike dokument te doen het. waarvan die waarde moeilik oorskat kan word.-1 Hierin word verhaal hoedal in jong man. Pkidha. tot bekering gekon het as gevolg van in wonder wat Addai in Arbela verrig het. Toe sy vader dit bemerk is Pkidha aan vreeslike martelinge onderwerp en in in donker kamer toegesluit. Hy het ontsnan en vir Addai gaan soek. maar kon hom nie vind nie Naderhand het hy verneem dat Addai na die dorpies in die bergagtige omstreke vertrek het on die Evangelie daar ook te gaan ver. 
kondig. (liteindelik het hy Addai daar gevind. ongeveer vyf jaar lank as sy leerling (dissipel) by hom vertoef en is daarna deur Addai die hande opgelê en teruggestuur na Arbela om daar as biskop op te tree."-2 Volgens Mingana was hy biskop vanaf 104 tot 114 n.C. sodat sy bekering moes plaasgevind het gedurende 99 n.C. ${ }^{23}$

Van Pkidha en sy opvolgers word allerlei interessante besonderhede en wetenswaardighede in die Kroniek verhaal. So word. onder andere, verhaal dat na Pkidha se dood in 114 n.C. daar vir 'n aantal jare geen biskop was nie. Ses jaar later het Mezra, die biskop van Beth Zabhdai saam met 'n karavaan van handelaars in Arbela aangekom. Na sy koms aan die Christene bekend geword het, het hulle hom dadelik versoek om "n diaken. Simson, as biskop te wy, wat hy dan ook doen."- Van 'n latere biskop. Noag. lees ons dat sy ouers Palestynse Jode was wat van Jerusalem af gekom en hulle in Arbela gevestig het omdat daar baie Jode was." Van verdere belang i.v.m. die Kerk in Adiabene is veral ook die feit dat die grootste aantal van die eerste biskoppe van hierdie bisdom suiwer Ou-Testamentiese of Joodse name gehad het, t.w. Simson. Isak. Abraham. Noag en Abel." $"$ "s

Dit is van belang dat ons op hierdie stadium kennis neem van die feit wat Josephus in die twintigste boek van sy Amtiquitutes vermeld, nl. dat koning lzates van Adiabene, sowel as sy moeder Helena. openlik die Joodse geloof aanvaar het teen ongeveer 40 n.C ${ }^{*}{ }^{7}$ Hoelank daarna hierdie dinustie nog die Judaistiese geloof bly aanhang het kan nie met sekerheid bepaal word nie. Dit moes egter minstens etlike dekades geduur het.

Hierdie feite wys in die rigting van 'n moontlike Joods-Christelike corsprong vir hierdie gemeente en toon aan ons die belangrike rol wat reisende handelaars en hulle mede-reisigers moes gespeel het in die totstandkoming en voortbestaan van hierdie Kerke in die Ooste."

Indien die Christendom teen die einde van die eerste eeu n.C. reeds so ver na die (Ooste deurgedring het en tot so 'n mate as wat uit die Kroniek van Arbela blyk. kan. myns insiens, hieruit met reg gekonkludeer word dat dit teen hierdie tyd dan beslis al in Edessa gevestig was." Edessa lê immers maar ongeveer 160 myl oos van Antiochië op die hoofweg na die (Ooste terwyl Arbela omtrent nog tweemaal soveel verder ooswaarts lê op dieselfde weg met Beth Zabindai tussen die twee. nader aan Arbela. Edessa was gedurende daardic tyd ook beslis 'n baie belangriker sentrum as Beth Zabhdai. Dit is dus heeltemaal logies om te konkludeer dat, indien Beth Zabhdai reeds $n$ bisdom was, die Christendom beslis ook al in Edessa gevestinmoes gewees het.

Antiochië self is ook omtrent tweekeer sover van Jerusalem af gelee as wat Edessa van Antiochie af verwyder is. Dit is dus onmoontlik om te aanvaar dat die Evangelie teen dic helfte van dis eerste eeu n.C. Antiochië al bereik. en daar in bloeiende gemeente tot stand gebring het. terwyl dit nog bykans in honderd jaar sou dulur voordat dit deurgedring het tot in Edessa soos Burkitt. onder andere, beweer." Dit is wel waar dat Antiochie nog binne die grense van die 
Romeinse ryk geleë was en Edessa daarbuite. In daardie lyd was dit egler geen groot belemmering nie veral aangesien Edessa op hierdie tydstip ' $n$ klein onafhanklike koninkrykie was en nie deel van die vyandiggesinde Parthiese ryk gevorm het nie.

In verband met die verbreiding van die Christendom na Edessa en omstreke, of breër gestel, na die Ooste. is daar nog 'n belangrike aspek wat ons nie uil die oog mag verloor nie. Hierdie feit is herhaaldelik al deur skrywers, veral kerkhistorici, beklemtoon. Die heel jongste publikasies in hierdie verband wat ek kon raadpleeg was die van Zernov" en van Daniélou en Marrou.:- Dit is nl. dat in die Nuwe Testament (en dan veral in die Handelinge van die Apostels) vir ons slegs die aanvanklike werksaamhede van Petrus e.a. ten opsigte van die verbreiding van die Evangelie in Judea en Palestina verhaal word en daarna uitsluitlik die sendingarbeid van die apostel Paulus en sy medewerkers en selfs dit blykbaar ook nie eers in sy hele omvang nie.

Van die werksaamhede van die ander apostels word absoluut niks gemeld nie. terwyl dit tog ondenkbaar is dat hulle geen deel sou gehad het aan die verkondiging van die Evangelie buite die grense van Judea nie, veral gesien in die lig van Jesus se herhaalde opdrag aan hule in hierdie verband (0.a. Matl. 28:19 en Hand. 1:8). Veral die apokriewe handelinge en geskiedenisse van die apostels toon aan ons dat die Kerk van die eerste eeue al hierdie gedagtes gekoester en die behoefte gevoel het aan meerdere kennis in verband met die werk. saamhede van die ander apostels. Hiermee wil ek geensins beweer dat die Nuwe Testament nie volledig is nie. Die doel van die Skrif is tog beslis nie om 'n geskiedenisverhandeling te wees nie, maar om die openbaring van God le bied wat vir die gelowige nodig is om te weet.

Ten minste somnige van die mededelinge van die Nuwe-Testa. mentiese apokricwe en ander boeke kan op ou oorlewerings gebaseer wees sodat. veral in die geskiedkundige gegewens, wel hier en daar 'n kern van waarheid gevind kan word.

Om die saak andersom te stel: Indien die Skrif ons niks aangaande die sendingarbeid van Paulus meegedeel het nie. sou die hoogste verbeeldingsvlugte nic in staat gewees het om al sy arbeid i.v.m. die verbreiding van die Evangelie te kon bedink nie. En. indien iemand dit dan wel sou gewaag het on te beweer dat hy bykans die hele Klein-Asie. Griekeland, ltalie en miskien selfs tot in Spanje deurreis het om die Evangelie daar te plant en oral gemeentes tot stand te bring en hulle herhaaldelik te besoek -.. wie sou dit geglo het?

Addai se naam kom so herhaaldelik voor as sendeling in die Noord-ooste dat ons dit byna al as waarheid moet aanvaar dat hy in werklik lewende persoon was! Ons het verneem hoedat sy naam in een bron genoem word as verkondiger van die Evangelie in Edessa. in ander onafhanklike bron verbind sy naam aan Adiabene. terwyl in derde weer beweer dat hy, saam met Mari. die eerste missionaris was wat die Evangelie in Karka. die teenwoordige Kirkuk. verkondig het.

Indien Thomas inderdaad die apostel was aan wie die kerstening van Parthic opgedra was, is dit ook waarskynlik dat hy. op sy wey 
Jaarheen. Jeur Edessa sou gegaan het en die Evangelie aklaar verkondig het. Dit is tog ondenkbaar dat hy die hele reis sou onderneem het en nêrens op sy honderde myle lange reis sou vertoef en nooit van die wonderbare Evangelie, wat aan hom toevertrou is. sou getuig het voordat hy Parthie self bereik het nie.

Hierdie is egter slegs gissings, hoewel dit miskien tog nog later mag blyk nie so baie vér van die waarheid af te wees nie. Op hierdie stadium en volgens die huidige stand van ons kennis kan nie die naam van een of ander besondere persoon genoem word as die eerste verkondiger van die Evangelie in Edessa nie. Hierdie feit op sigself hoef ons egter nie te ontmoedig of te verontrus nie. Selfs ten opsigte van Rome, wat vir soveel eeue so 'n belangrike rol in verband met die Westerse Christendom sou vervul, weet ons ook nie wie die eerste persoon is wat die Evangelie aldaar verkondig het en wanneer dit geskied het nie." Tradisies hieromtrent is daar wel genoeg maar afdoende feite nie. Tog weet ons dat dit heel spoedig na Pinkster moes geskied het" en heel waarskynlik die werk van (Joods-) Christelike reisigers moes gewees het.

Op grond van my ondersoek is ek self teen hierdie tyd oortuig dat die Evangelie nie eers gedurende die tweede een n.C. Edessa en omstreke bereik het nie, soos byna algemeen aanvaar word, maar baie beslis gedurende die eerste eeu al daar weerklink het.

Op hierdie stadium moet ons dan ook 'n gedagte wat eerder al genoem is, van naderby betrag. Dit is $\mathrm{nl}$. dat sowel in Adiabene as by die verhaal van Addai van die Evangelie-verkondiging in Edessa sprake was van Jode en/of Jode-Christene. Hiermee wil ek ook die gedagte verbind van die rol wat reisigers of reisende handelaars sowel as uitgeweke gelowiges vervul het ten opsigte van die verbreiding van die Evangelie. Ons weet dat dit aan hierdie ..gewone" gelowiges te danke is dat die Evangelie Antiochic so spoedig al bereik het ${ }^{3 i}$ Naastenby dieselfde sal ook wel geld vir Rome en vir Egipte. Van lg. lees ons in Hand. 18:24 dat 'n sekere Jood, Apollos. uit Alexandrië in Efese aangekom het wat ,.'n welsprekende man" en ..magtig in die Skrifte" was "en vurig van gees. het hy gespreek en die dinge aan. gaande die Here noukeurig geleer". Waarom kan ons dan nie aanvaar dat die Evangelie op dieselfde wyse ook sy verskyning in Edessa en in Adiabene gemaak het soos die volgelinge van Johannes dic Doper bekeerlinge in Alexandrie verwerf het en hulle hul leringe weer verder uitgedra hot nie? ${ }^{3 i}$

Wat hier veral van baie groot belang is. is die feit van die ...andersoortigheid" van die Siriese Christendom teenoor dié van die Weste. Tot onlangs nog is dit toegeskrywe aan die invloed van die asketiesc en enkratitiese inslag van die Diatessaron van Tatianus en die optrede van sekere sektariese rigtings gedurende die tweede eeu n.C." Dic onlangs ontdekte Evangelie van Thomas" dwing ons egter int ander konklusies. Hieruit blyk nou baie duidelik dat Tatianus beslis nie so oorspronklik was as wat selfs so 'n groot deskundige op hierdie gebied as Vööbus aan die begin van die afgelope dekade nog gedink het nie." 
Die Diatessaron van latianus was wel in heel besondere en meesterlike werk wat die samestelling daarvan betref. Ten opsigte van die asketiese en enkratitiese inslag daarvan. selfs die samevoeging van afsonderlike tekste om daaraan 'n besondere nuansering te verleen. blyk dit nou nie meer in so ' $n$ mate dic werk van 'n meesterhand te wees soos wat voorhcen aanvaar is nie. Die Diatessaron bied hierin slegs die voortsetting van ou tradisies en oortuigings wat die Siriese Kerk lank reeds eie was. myns insiens. heel van die begin af. Soos ek elders breedvoerig aantoon vind ons onteenseglike bewys hiervan reels in die Odes van Salomo maar veral in die Evangelie van Thomas.":

In hierdie geskrifte het ons 'n voortsetting van die Joods-Christelike tradisies van die eerste eeu n.C. waaruit later die sektes bekend as die sogenaamue Ebioniete en Elkesaiete voortgekom het. Dat hierdie Christene uit die Jode. wat kort voor die beleg van Jerusalem in die Oos-Jordaanse streke (veral in Pella) gaan woon het, die Evangelie volgens die Hebreërs gebruik het, word algemeen aanvaar. Dat Tatianus ook hierdie Evangelie gebruik het by die samestelling van die Diatessaron is 'n gedagte wat reeds in die vierde eeu skriftelik vasgeslê is.." Nou is die sogenaamde Evangelie van Thomas ontdek. wat ook lank voor die Diatessaron moes ontstaan het en wat baie duidelik toon dat laasgenoemde daarvan afhanklik is en dus slegs, soos reeds gesê. die voortselting van ouer tradisies bestendig.

Nadat ek al vér gevorder het met my studie het die artikel van Gibson" wat pas verskyn het. onder my aandag gekom. Gibson se gedagtes neig in presies dieselfde rigting as waartoe my eie studie my gelei het. met slegs die verskil dat (jibson nog nie die gegewens. wat die Evangelie van Thomas bied. in sy redenering bygewerk het nie. terwyl dit vir my die sluitsteen vir hierdie hele opvalting bied.

My sienswyse in verband met die ontstaan van die Siriese Christendom wil ek dan soos volg stel:-

Sedert die wegvoering in ballingskap van die tienstamme-ryk in 722 v.C. en van Juda in $587 / 6$ v.C. was daar altyd Joodse gemeenskappe ten ooste van Palestina: groter gemeenskappe as ten weste daarvan. Daar was 'n lewendige onderlinge verkeer tussen hierdie Jode van die diaspora en die van Jerusalem. Dit blyk onder andere uit die feit dat Hillel. een van die grootste Joodse geleerdes van die laaste jare v.C. van Babiloniese herkoms was. maar tog in Jerusalem 'n baie belangrike rol vervul het. Die Jode van die diaspora het Jerusalem gereeld besoek - - ten minste dié wat daartoe in staat was. Op die Pinksterfees was daar "Jode en Jodegenote" teenwoordig van oor die hele bekende wêreld. Die helfte van die name wat hier opgeson word is van volkere ten ooste van Palestina."

Die mees natuurlike en logiese afleiding hiervan is dat. na die vernietiging van stad en tempel in 7() n.C. deur Titus, sommige van die inwoners van Jerusalem. Jode en Joods-Christene. ooswaarts sou gevlug en aansluiting by hulle volksgenote in Edessa. Arbela en omgewings sou gesoek en gevind het. Ons weet wel dat baie van die Christene hulle voor die beleg reeds in die oos-Jordaanse streke gaan 
vestig het. Dit sluit egter nie uit dat sommige hulle reeds dadelik al verder oos-en/of noordooswaarts kon gaan vestig het nie.

Dit is ook moontlik dat van dic Jode-Christene reeds vroeër al. selfs voor die val van Jerusalem. op hul handelsreise na die Ooste hul geloof na genoende en ander grotere sentra kon verbrei het. Ons weet inmers dat die Jode onder die Romeinse heerskappy uit sekere professies uitgesluit was en hoofsaaklik op die beoefening van die handel en ambagte aangewese was vir hul lewensonderhoud. Dieselfule geld ook vir die Christene wat aanvanklik deur die Romeinse owerheid as 'n Joodse sekte beskou is.

Ons het ook reeds gewys op die belangrike rol wat handelaars en reisende karavane sowel as Christene van Joodse oorsproing in hierdie wêrelddeel ingeneem het in verband met die verbreiding van die Evangelie.

Hoe dit ookal sy, ons kan ons nie meer verlaat op die gageweis van die Kroniek van Edessa om op grond daarvan te probeer tepaal wanneer die vroegste moontlike tydstip was waarop die Christendom sy verskyning in hierdie streke gemaak het nie. Die Kroniek van Arbela toon reeds die onhoudbaarheid van so "n standpunt.

Indien ons die ooswaartse verbreiding van die Evangelie (en van die Christendom) so sien as die werk van hierdie mense van JooklsChristelike oorsprong. bied die eiendardige eiesoortigheid van die Siriese Christendom ook glad geen probleen meer nic. Inteendeel. dit is dan 'n direkte voortsetting van die besondere geloofsnuansering soos ons dit vind by die mense wat dit daarheen oorgebring het.

Hierdie gedagte dat die Siriese Kerk se oorsprong by die Christene van Joods.Christelike herkoms gesoek moet word. hel gedurende die afgelope tyd steeds meer na vore gekom as 'n vermoede. (jibson het nou in verband hiermee (vir sover ek kon vasstel) in radikale nuwe stem laat hoor in die sin dat hy die lyn wil deurtrek van Oumran af deur die Arameessprekende Kerk heen tot in Edessa." Hierdie gedagte is vir my beslis nie so vérgesog nic. Jesus se prediking (en gevolglik ook die (hristendom) het blykbaar nie juis noemenswaardige aanklank gevind by die Sadduseeds nie; 101 " $n$ mindere mate wel by die Fariseèrs; maar hoofsaaklik by dié groep onder die Jode wat hulle ontuis gevoel het by beide hierdie rigtings. en onder diegene moet seker ook die Oumran-gemeenskap getel word. Een van Jesus se 12 dissipels heet ...Simon wat Yweraar genoem word"'i: 'n henaming wat duidelik heenwys na die ...sektariese" groepe onder die lode van daardie tyd.

As ons (om nie sover terug te begin as (jibson nie) die lin deurtrek van die Joods-( Christclike Kerk met die Kvangelie van die llebreës af, deur die Odes van Salono en die Fvangelie van Thomas heen tot by die Ou.Siriese Evangelictekste. die Diatessaron. die Handelinge van Thomas, ens. dan vind ons min of meer een deurlopende lyn.

Hoewel daar al baic bespiegel en geshrywe is oor die JoodsChristelike sektes, veral die Ebioniete en die Elkesaiete weet ons eintlik nog maar weinig ontrent hulle ondat die outentieke bronne maar weinig is en mekaar soms selfs weerspreek. Wal wel histories alan- 
wyshadr is, is dat die Christene van Palestina en veral van Jerusalem. voor die val van die stad in 70 n.C.. hulle hoofsaaklik in die oosJordaanse streke gaan vestig het. Wat ook onbetwisbaar is. is dat genoemde sektes se ontstaan en aanvanklike uithreiding ook in hierdie omstreke gesoek moet word. Hullc het dus blykbaar uit die gelederc van hierdie (hristene voortgekon. Verder is dit duidelik dat die Evangelie van Matthéüs veral vir dic Jode geskrywe is en daarom heel waarskynlik ook dié Evangelie-beskrywing is wal deur die JoodsChristene gebruik is. In verband hiermee is dit interessant on te let op wat Epiphanius ons meedeel aangaande die Ebioniete. $\mathrm{Hy}$ sê (Panarion XXX, 3 en 13): ..Hulle aanvaar die Evangelie van Matthéüs en gebruik dit alleen. terwyl hulle dit noem die Evangelie volgens die Hebreërs. Maar die Evangelie van Matthéiss wat hulle besil is nie volledig nie. dog vervals en vermink"."

Dit is ook duidelik dat ons die oorsprong van die enkratitiese. asketiese en puristiese neigings van die Siriese Christendon tot hierdie groepe kan en noet herlei. Kan dit dan aan blote toeval toegeskrywe word dat dieselfde gedagterigting soos in rooi draad al bogenoende geskrifte deurweef en terselfdertyd die eintlike. besliste anderssoortige karakter en inslag vorm van die Siriese Christendom teenoor die hele Westerse Christenheid?

()p hierdie vraag wil ek antwoord met in besliste: Nee! Nee. dit is nie toevallig nie. Dit toon vir ons die gang van een aaneenlopende. déurlopende lyn: Dit was veral reisigers. handelaars. vlugtelinge of miskien selfs nissionarisse van die Joods-Christelike kerk wat die Evangelie aan hulle volksgenote en aan die heidene oos van die Romeinse ryk oorgedra en onder hulle proselicte gewerf het. Van. selfsprekend hel hulle die geloofsnuanseringe wat aan hulleself eie was ook aan die bekeerlinge oorgedra. Hier in Sirie. waar die Kerk. in afsondering van dié van die Weste. gevorm is volgens hierdie gedagterigting het dit heel snoedig 'n eiesoortige Christenheid ontwikkel wat ongestoord sy gang kon gaan en sy andersoortigheid kon bestendig gedurende die verloop van meer as ' $n$ eeu van selfstandige ontwikkeling.

Miskien mag ek hier terloops daaron wys dat hierdie rigting log ook nie so heeltemaal vreemd aan die Nuwe Testament self is nie. (Ons weet nie wie die Brief aan die Hebreërs geskrywe het nie. Die inhoud en opset van hicrdie brief is so gans anders as die van al Paulus se briewe dat dit moeilik aanvaarbaar is dat hv die outeur kan wees. Hoofsaak is egter dat dit $n$ brief am die Mehrë̈rs is en deur hierdie henaming kom ons al nader aan die Ou Testament. aan die Jode en aan die Jooxls-Christene."' Die inhoud van hierdie brief toon dan ook duidelik dat dit geskrywe is met die oog op en vir mense wat die ()u Testament ken om aan die hand van die Ou Testament vir hulle aan te toon dat die Christendom dic voortsetting van die ()u-Testamentiesc geloof is. Hier het ons dus eintlik nresies dieselfue lema as dié van die lvangelie volgens Malthéiis. Die brief van Judas het ook 'n duidelike loods-Christelike inslag. In laaste maar nie die minste nie. skrywe lakobus sy brief .aum die wastf va:nme wat in 
die verstrooiing is". Die feit dat so lank getwyfel is of hierdie brief in die kanon van die Nuwe Testament opgeneem moet word weens die eiesoortige prediking daarvan in vergelyking met die meeste geskrifte van die Nuwe Testament is al getuienis genoeg vir die feit dat dit geskrywe is met die oog op die Christene uit die Jode en diegene wat hulle besondere sienswyse toegedaan was. Ek is geen Nuwe-Testamentikus nie en stel daarom slegs die vraag: Hou die Nuwe Testament nie hierin ook rekening met die Joods-Christelike gemeenskap se besondere eie-aard en met hulle proseliete buite die invloedsfeer van Paulus en van die Westerse Kerke nie?

Vir my lyk dit altans asof in die rigting gedink kan word. Ek dink ek waag ook nie meer as wat hewysbaar is nie as ek beweer dat ek tog iets van die ,teologie”, van die opvattinge en van die geskriftc van die Jode gewaar in die brief van Judas: dat ek ook iets van die puristiese. enkratitiese en/of werkheiligheidsideaal aanvoel in die brief aun die Hebrë̈rs en in die brief van lakobus aan die twaalf stamme wat in die verstrooiing is, of, ten minste, dat albei hierdie briewe elemente bevat wat in hierdie rigting geinterpreteer of misverstaan kan word.

Maar ek moet terugkeer tot die oorsprong van die Siriese Christendom. En dan wil ek. wat ek reeds gesê het. opsommenderwyse so stel:

1. Dit is moontlik dat spesifieke name aan die oorsprong van hierdie „eeiesoortige" Christendon verbind kan word en dan wel veral dié van Thomas en van Addai.

2. Ons besit egter geen bewyse hiervoor nie.

3. Daarom is dit beter om ons te bepaal by dit wat meer waarskynlik is, nl. dat die eerste Evangelieverkondiging in hierdie wêrelddeel heel waarsk vnlik die werk van enkelinge uit die ..gewone" stand van die gelowiges was - hetsy selfaangestelde (of gestuurde) missionarisse, voortvlugtende gelowiges. handelaars, of reisigers wie se harte vol was van Christus en hulle monde daarom oorgeloop het van hulle nututgevonde geloof.

4. Dit is meer as waarskynlik dat hierdie draers van die Evangelie van Joods-Christelike oorsprong was en dus hul eie siening van die Christelike geloof aan diegene oorgedra het tot wie hulle die Evangelie gebring het.

5. Hieruit volg logies dat hierdie draers van die goeie boodskap meer met enkelinge. gesinne en/of klein groepies in aanraking sou gekom het as bv. die apostel Paulus wat op die Areopagus. in die sinagoges en op ander openbare plekke die Evangelie verkondig het. Soms aan baie groot skares tegelyk.

6. Daarom was die vroeë Christendom geen noemenswaardige ..nasionale" faktor in Edessa nie en vind ons gevolglik ook geen vermelding daarvan in die Kroniek van Edessa nie.

7. Nogtans kan. met in baie groot mate van sekerheid, gekonstateer word dat die Christendon Folessa nie eers gedurende die tweede 
ecu bereik het nie. Inteendeel, die blye boodskap van die Evangelie het in hierdie stad en koninkryk ook in die eerste eeu reeds weerklink en aanklank gevind by die uitverkorenes van God.

H. S. PEI.SER.

(Gelewer voor G.T.V.. Pretoria, 1967)

\section{VERWYSINGS}

1. In hierdie studie word onder dic henaming ...Siriese Christendom Kerk" verstaan dié deel van die vroee Christendom Kerk oos van Antiochie. uaarvan die liturgicse taal (soewl as die spreek- en skryftaal) Siries was in teeselling met dié deel van die Kerk Christendom binne die Romeinse rỵk. waarvan die liturgiese taal Grieks was.

2. Vgl. F. C. Burkitt. Early Easıern Christianim, (hierna aangehaal as: E.E.C.). Londen, 19(24, p. 6: .. The early history of the Syriac-speaking Church is to a certain extent a matler of conjecture and inference": vgl. ook sy Evangelion I)a-Mepharreshe, Cambridge. 19(1)4. vol. II. D. I.

3. (i. Phillips. The Mocrine of Addai, the Apostle, I onden. 1876 en ander uitgawes.

4. Dil is 3132 n.C.

5. Vir aanhalings uit die I eer van Addai het ek bg. teks van Phillips gebruik in my eie Afrikaanse vertaling: vir dic Afrikaanse weergawe van eiename sluit ek aan by Phillips se Engelse weergate.

6. Aangesien hier in ander ww. gebruik word as bv. in Joh 17:3 vertaal ek hier doelbewus nie met .volbring" nie; hoewel hierdie hele brief sterk invloed van die Evangelie volgens Johannes vertoon.

7. Vgl. die Londense Inaily Express van 2 Mei $19(00$ : vgl. ook Burkitt. E.E.C. p. $16 \mathrm{vv}$.

8. Slegs in die Siriese Kerk is die apostel Thomas so genoem, vgl. o.a. my artikel: The Origin of the Syrian Asceticism or Monasticism (hierna aangehaal as: Syrian Asceticism). in Biblical Essays. Potchefstroom. 1966. pp. 122.3 en die daargenoemde veruysings na Klijn en Puech.

9. Dit is opvallend dat die lesing ..72" in Luk. 10:1 ooreenkom o.a. met Syr Cur en Syr Sin - vgl. o.a. Burkitt. Evamgelion Da-Mepharreshe, vol. I, p. 310 in die teks en voetnool 1 . waar verwys word na Act Thomae 176 en hierdie Addai-teks. Volgens in persoonlike mededeling van prof. Van Selms het die Luikse diatessaron ook dieselfde lesing en gee die apparaat daar ook nog. hehalwe hg. outoriteite. die Sahidiese vertaling en verskillende plekke uit Afrem (Efraim) aan. Dit hlyk dus dat hierdie lesing taamlık uyd verbreid was in die Siriese tekstradisie

11). In hierdie teks (van Phillips) staan Antiochic. In die onvolledige teks van dic MS in die Britse Museum. wat deur Cureton uitgegee is. is die stad se naam egler korrek aangegee as Rome.

11. Vgl. die aanhef van die Handelinge van Thomas: daar hestaan verskele uitgawes hiervan. o.a. A. F. J. Klijn. The Acts of Thomas. Supplement to Novum Testamentum. vol V. Leiden. 1962.

12. Vir verwysing in die ou Christelike l.iteratuur vgl. o a Klijn. a.u.. p. 27.

13. Vgl. o.a. I J. Tixeront. Les Orixines de l't.glise d'Edesse el la légende d'Ahxar, ftude critique. Palys, 1888. p. 155. wat dit stel op 232 n.C.: teruyl die Kronick van Edessa (inskrywing 38) dit stel op 22 Aug. 705 ( $=394$ n.C.). $M . i$. lê die sleutel vir die oplossing van die verskil in datums opgesluit in dic mededeling van die kronick: .. . . het hulle dic glossocom van Mar Thomas na "y srool tempel kerk toe gehring" (onderstreping van my). Die stoflike oorskot van Thomas is dus hlykbaar in 232 na Edessa toe gebring en erens bygele: leruyl dit in 394 deur hiskop (yrus oorgebring is na in 
ereplek in die katedraal (= groot kerk).

14. Vgl. o.a. A. F. J. Klijn, Edessa, de srad van de apostel Thomas, Baarn, 1962.

15. In 216 n.C. is Edessa by die Romeinse ryk ingelyl.

16. Vgl. W. Wright. A pocryphal Acts of the Aposfles, Londen. 1871 (vol. I. Siriese tekste: vol. II, Engelse vertalıng). vol. II. p. 3.

17. A.w.. p. 54 .

18. In die opskrif van hierdie geskrif. W. Wright. a.w. p. 3. word aan ons meegedecl: .. This history was composed by Eusebius of Cacsarea concerning St. John. who found it in a Greek book. and it was Iranslated into Syriac. when he had learned concerning his way of life and his birth and his dwelling in die city of Ephesus. after the ascension of our Lord to Heaven."

19. Opgestel deur Msiha Z,kha in die 6de eeu: ontdek en gepubliseer met 'n Franse vertaling deur A. Mingana in Sources Siriaques, vol. I. Mossoul. Leipzig. 1907.

20. P. Peeters, La passionaire d'Adiabenc in Analecta Bollandiana. vol. X'LIII. Bruxelles. 1925. pp. $261-304$

21. Vgl. o.a. E. Sachau, die Chronik von Arbela. Ein Beitras zur Kenmmis des äleston Christentums im Orient, in Abhandlungen der Berliner Akademie. 1915: A. Baumstark. (ieschiche der syrische'n Literatur. Bonn. 1922. p. 134 w. en A. von Harnack. Die Mission und Ausbreitumg des Christentumıs. Leipzig. 1924. p. 684.

22. Mingana. Sources Syriaques, p. 2 \&. (vertaling p. 77 k).

23. $\mathrm{Vgl}$. veral a.w., p. 157.

24. A.w., p. 4 v. (vertaling. p. 79 v.).

25. A.w., p. 13 (vertaling. p. 89).

26. A.w., vgl. veral die lys van hiskoppe op p. 1578

27. Vgl. o.a. dic uitgawes van B. Niese. Berlyn. 1890, p. 292; ook P. Kahle. The (airo (ienisa. ()xford. 1959=- p. 270 $\mathrm{vv}$.

28. Vgl. A. Vobbus. Early Versions of the Now Testameml (hierna aangehaal as: Early Versions), in Papers of the Estonian Theological Socicly in Exile. no. 6. Slockholm, 1964. p. $67 \mathrm{kv}$.

29. Vgl. A. Vöobus. Studies in the History of the Gospel Tent in Syriac (hierma aangehaal as: Studies). ('.S.C.O.. vol. 128. Louvain. 1951. p. 14 v.

30. Vgl. Burkit, E.E.C.. p. 9.

31. N. Zernov, Eastern Christendom, Londen. 1961. p. 19

32. J. Daniélou en H. Marrou. The Christian Commries, vol. I. The First Sit Hundred rears, Londen. 1964. p. $18 \mathrm{v}$.

33. Georg Hoffmann. Auszuge aus syrischen Aklen persischer Märlyrer in Abhandlungen für dic Kunde des Morgenlandes. vii. 3 l.eipzig. 1880, p. 45: Addai se naam word hierin aun nog meer plekke verbind. vgl. pp. 180. 371.

34. Vgl. o.a. H. Ridderbos. Commentaar op he' Nicun'e Testame'til. Aan de Romeine'll. Kampen. 1959. p. $5 \mathrm{v}$.

35. Toe Paulus. heel waarskynlik in 57 of 58 n.C. sy brief aan die Romeine geskrywe het was daar al baie ( hristene in Rome woonagtig. igl. Ridderbos. a.W., pp. 5-19.

36. Vgl. Handelinge $11: 19-21$.

37. Apollos was natuurlik nog geen ..Christen" nie, want hy het ..net van die doop van Johannes geweet". Hand. 18:25.

38. Vgl. hoofstuk 1. maar veral hoofstuk $V$ van my (nog ongepublisecrde) proefskril: Rabbula, die Biskop van Edessa (hierna aangehaal as: Rabbula): ook die reedsgenoemde Syrian Asceticism. p. $119 \mathrm{vw}$.

39. Veral die Marcioniete en Montaniste word in hierdie verband genoem. vgl verderaan.

40. Vir vollediger besonderhede vgl. Pelser: Syrian Ascelicion. pp. 121-125 en al die bronne daar genoem.

41. Vgl. die aanhalings t.o.v. sy standpunt in hierdie verband in Pelser: Rahbula. hoofstukke IV en $V$. sowel as in sy eic aangehaalde Herke. 0.a. Studies. pp. 16. 20. 21. 24, 34 en 167: Early Versions. pp. I en 78.

42. Vgl. o.a. Pelser: Syrian Asceticism. pp. 119-125.

43. Epiphanius (4de eeu) meld dat sommige mense ban sy tyd die Diatessitron 
vereenselwig het met dic Evangelie volgens dic Hebreers. terwyl Victor van Capua in die bde ecu die werk van Tatianus in Diapente genoem het. en nie Dialessaron nie. wat inhou dat Tatianus byf bronne. en nie vier nie. gebruik het by die samestelling van sy geskrif. Vir vollediger besonderhede in verband hiermee vgl. (;. Quispel. Some Remarks on the Gospel of Thomas in: New Testament Studies, vol. 5. Londen. 1958 9. p. 283.

44. J. ('. L. (ibson, From Qumran to Edessa or the Aramaic speaking Church before and after $70 \mathrm{~A} . L$ ). The Annual of Leeds University Oriental Society. vol. V. 1963-1965. Leiden. 1966. pp. 24-39.

45. Vgl. Hand. 2: 9. Il: vgl. ook Gibson. a.w., p. 26.

46. A.w. veral pp. 27 vv.: vgl. egter ook H. Kosmala. Hebräcr-EssenerChristen, Leiden. 1959 en die daarin genoende voordrag van dr. Yigal Yadin (vgl. p. VII): sowel as andere wat al meer 'n verband soek lussen die Christene en veral dic Hebreerbrief en Qumran. o.a. aan die hand van Hebr. $11: 38$.

47. Lukas $6: 15$.

48. Vgl. o.a. Jean Daniélou, The Theology of Jewish Christianity. vol. I van Development of Christian Doctrine before the Council of Nocaca. vertaal deur John A. Baker, londen. 1964. p. 58.

49. Vgl. ook die a.w. van Kosmala, veral hoofstuk I ..Der lfebräerbrief und seine Empfänger. $p .1 \mathrm{v}$. en in studiegids van l. H. Eybers van die Universiteit van S.A.. Iie Brief aan die Mebrecrs (nic in die handel verkryghat nie). 